supervision of government departments' commitment to research. That would be a decisive break from the ethos of the Rothschild Report, which decreed in 1971 that all departments should equip themselves with a chief scientist capable of being an effective "customer" for research, but it is a necessary break: departments have since been pusillanimous in their regard for research, all too ready to count it as a dispensable cost when budgets are tight. If Britain ends up with a Civil Research Agency responsible to OST, that will be entirely welcome.

The worries are different. The "scrutiny" is being conducted by civil servant members of the government's "Efficiency Unit", who are not chosen for their feeling for research, has been done in a hurry (90 days) and is likely to have been driven by the fashionable view that privatization in some form (outright sale or management by private contractors) is inherently virtuous. The Royal Society is right to fear that the outcome may pay scant regard to the principle that much research is not a commodity but an activity that is valueless without continuity. Without its Central Veterinary Laboratory (one of the 53 being scrutinized), the government would be in an even greater pickle in knowing how to deal with the current outbreak of bovine spongiform encephalopathy (BSE), for example. And is it possible to run an effective laboratory for the management of safety standards for vaccines without a continuing fund of expertise in the field?

That is one cause for alarm. The Royal Society also fears that when the scrutiny report is published, the government will already have made up its mind. The assurance from $\mathrm{Mr}$ William Waldegrave, the science minister, that consultation will be genuine is therefore welcome, brief though the period allowed (another 90 days) may be. The more enduring cause for concern is that the outcome of the scrutiny, if it should allow government departments to indulge their inclination to wash their hands of responsibility for research, will leave the British Civil Service even less well-equipped than at present to fight its government's corner in an increasingly technical world, in Brussels and such places. OST will have its work cut out to shoulder that whole burden, but there may be no choice.

\section{Britain's block votes}

The British government is once again in the European doghouse, this time for good reason.

How should the interests of minorities be safeguarded in circumstances where decisions are normally made by counting votes? The question often arises, and is answered differently in different circumstances. In many countries, Russia for example, a popular vote on an amendment to the constitution requires a two-thirds majority to succeed. In many places, juries in court trials are required to give verdicts that are unanimous, but elsewhere a specified majority (say 10 out of 12) will suffice. On the United Nations Security Council, any one of the five permanent member govern- ments can unilaterally veto a decision it does not like.

It used to be like that on what is called the European Council, at which representatives of member governments, usually ministers, adopt (or otherwise) European legislation. But by the common consent of the 12 present members, the rules were changed in 1987 to weight the votes of different member states crudely by their population (the four large members have 10 votes each, smaller member states have 4,3 or even 2, making a total of 76). At the same time, it was agreed that a minority seeking to block the adoption of proposed legislation must assemble 23 votes, or roughly 30 per cent, to succeed. None of this touches the vast range of European policy-making concerned with foreign policy, security and defence, where the assertion of an "overriding national interest" will suffice to give a single member state a veto, as of old.

So what happens when new members join the European Union (EU)? (The good news that Austria, Finland and Sweden now wish to join has since been followed by an agreement with Norway.) They, too, must evidently have a weighted vote. The negotiations so far (to which Britain has been privy) would augment the total number of votes to be cast at a meeting of the European Council to 90 and the required blocking minority vote to 27 , or 30 per cent of the new total. The British government, which has creditably been consistent in its backing for the enlargement of the EU, has now objected to the arithmetic, on the grounds that any increase of the number of votes required to block a piece of European legislation will further diminish the autonomy of member states.

Whether or not a compromise will have been reached at this week's meeting of foreign ministers in Brussels, the fuss the British are making is disingenuous humbug. (Spain also protests, but from fear that the outcome of the accession of the northern states will be a decrease of the funds available for Mediterranean agriculture, and in any case has done so less obdurately.) The British objection to the proposed voting regime springs not from an objective appraisal of what would be just, but from domestic political considerations: the government has only just emerged from a bruising battle with its own supporters over the ratification of the Maastricht Treaty, and wishes to be seen to be acting "tough" on Europe in advance of the elections to the European Parliament to be held throughout Europe in June. The circumstances have been widely reported, are generally understood and are discreditable.

In none of its calculations does the British government appear to have grasped that its wish to be "at the heart of Europe" (as the prime minister put it some months ago) is unlikely to be gratified by a row over the precise circumstances in which Britain (in concert with others) can vote down proposed legislation. It is especially disastrous that this should happen precisely when the British government should have been seeking to mend the damage done by the tawdry rhetoric of its internal squabble over Europe last year. If the outcome is that the government party's performance in the June elections turns out to be even worse than now predicted, that will be small comfort. 